\section{Astronomy in the} Brazilian Empire: longitude, an international congress and the quest for a universal science in the late nineteenth century*

\author{
Moema Vergara \\ Researcher, Museu de Astronomia e Ciências Afins \\ Rio de Janeiro - RJ - Brasil \\ orcid.org/0000-0003-1837-082X \\ moema@mast.br
}

Received on 6 Sept. 2017.

Approved on 21 Jan. 2018.

Translated by Derrick Guy Phillips
VERGARA, Moema. Astronomy in the Brazilian Empire: longitude, an international congress and the quest for a universal science in the late nineteenth century. História, Ciências, Saúde - Manguinhos, Rio de Janeiro, v.26, n.1, jan.-mar. 2019. Available at: <http:// www.scielo.br/hcsm>.

\section{Abstract}

There is no clear picture in the international historiography of Brazil's participation at the International Prime Meridian Conference in Washington of 1884. In Brazil there exists the prevailing interpretation that the Brazilian vote accompanied France for reasons of subordination. This work seeks to analyze this interpretation, by scrutinizing unpublished sources on the subject, such as the letters exchanged by Luiz Cruls both with the emperor and with his wife, as well as news articles in journals, annals and reports. In this article, an approach to the history of science was adopted that was concerned with the processes of institutionalization of astronomy in Brazil in the midst of a worldwide debate on the standardization and universalization of science.

Keywords: History of Astronomy; Longitude; Luiz Cruls (1848-1908); International congress. 


\section{The Washington Conference of 1884}

The International Prime Meridian Conference was yet another conference seeking to unify the longitudes and to establish a universal hour. ${ }^{1}$ For geographic location, over the course of time, a network of parallels and meridians projected on the earth's surface was used to indicate locations, with parallels enumerated from 0-90 degrees north and south of the Equator (latitude), which divides the Earth perpendicularly on its axis of rotation. The difficulty for establishing zero longitude lies in the fact that there is no distinct starting point on the meridian lines starting from the poles to the east-west positions. It is important to note that this way of calculating longitude was decided precisely at that conference - the proposal that was rejected was to cut the Earth longitudinally in 360 degrees. In the course of history, cartographers arbitrarily chose (generally an important landmark of the region) as the starting point for the prime meridian, which resulted in a series of railroad accidents and made navigation difficult (Bartky, 2007, p.1). It is important to add that, besides being a geographic coordinate, longitude is linked to the counting of time and is a fundamental element for the elaboration of time zones.

The problem of unification had already been raised in earlier international congresses, such as the first geography congress in Antwerp in 1871 for example. At this conference, there was a tendency to favor the adoption of the Greenwich meridian as the prime meridian because of the widespread use of the Nautical Almanac produced by that observatory. Nevertheless, many scientific works were still linked to the Paris meridian, mainly in geodesics, which rendered the final resolution of the Antwerp Congress inconclusive. According to Barky (2007, p.42), Émile Levasseur, a leading French geographer well known in Brazil, ${ }^{2}$ stated that the dispute was between only two meridians to be considered, namely Paris and Greenwich, and the choice reflected the prestige of each country in the international scene. This statement of Levasseur in 1871, which coincided significantly with the end of the Franco-Prussian War, succinctly expressed France's self-consciousness about the decline of its hegemony in the sphere of cultural influence, in which it had provided the standards of civilization and progress for the rest of the world. The quest for a centrality lost to the English power, in economic and political terms, may have been an explanatory element for the French performance at the Washington Conference in 1884 . It should be noted that the choice of a national meridian to be the universal standard has a powerful symbolic meaning of omnipresence in daily life around the globe.

The tension between the meridians of Paris and Greenwich persisted at the conferences in Rome and Washington in the mid-1880s. The Association Géodésique Internationale (AGI) received a demand from the Hamburg Senate for the unification of the coordinates. In the nineteenth century, the distances became even smaller with the telegraph, steam navigation and railroads. In the case of the Rome meeting, the request came from the Hamburg Senate, but could have been submitted by any other institution. Since unification was a pressing need, since, for example, with rail network densification in Europe and the USA, the lack of standardization generated daily inconvenience, as well as accidents on railways and difficulty in navigating in sundry longitudes. which meant reassessing the calculations constantly on the high seas (Galison, 2003). In other words, the need 
for a universal meridian was produced by an impact that those new technologies were generating at that juncture.

In 1883 the International Conference of Geodesics was staged and organized by the AGI in Rome and had as its objective the adoption of a unique prime meridian and the unification of time by the introduction of a universal hour. Brazil did not participate in this meeting, possibly because of the internal problems of the Imperial Observatory. ${ }^{3}$ At the opening session, the Washington Conference for the following year had already been announced with a view to resolving the impasse from the point of view of international relations (Hirsch, Oppolzer, 1883, p.8), since the Rome meeting, consisting of a panel of experts, did not have the power to persuade nations to adhere to a universal meridian in the civilian life of countries, as well as in drafting national maps and establishing time zones.

It is noteworthy that the result of that meeting in Rome was the choice of Greenwich as the prime meridian. Participants bore in mind that, in order to overcome the obstacle to international standardization, diplomacy was required. The final decision of the AGI Congress was based on the allegation of practicality, since much of the world's fleet already sailed along that meridian. France regarded this decision as a defeat and decided to form a preparatory commission within the scope of the Institute of France for the meeting of 1884 (Gapaillard, 2011).

In October 1884, forty delegates from 25 countries, from the spheres of both diplomacy and science, met in Washington to seek to establish a new agreement among nations on the zero-longitude meridian and start counting time from a common point. The inaugural session was held at the Diplomacy Hall of the US State Department and was opened by then Secretary of State Frederick T. Frelinghuysen, who reminded all present that they had the mission of giving a definitive solution to the preceding preparatory work both in scientific associations and earlier congresses. He finished his speech wishing them success and trusting that a satisfactory conclusion would be reached for the "civilized world." He gave the floor to the conference chairman, US Admiral C.R.P. Rodgers, who pointed out the importance of establishing a single longitude because, being a seaman, he was well aware of the confusion of having several meridians causing turmoil and danger to the crew.

In the first section of the discussions, the American delegate, astronomer Lewis Rutherfurd, proposed Greenwich as the prime meridian: "As the standard meridian that passes through the center of the transit window of the Greenwich Observatory" (Protocols..., 1884, p.41), as if it were a matter already decided, based on the result of the Congress of Rome of the previous year.

Immediately thereafter, the French delegate, Consul General Albert Lefaivre, rejected the decision. His colleague, the astronomer Janssen, argued that this assembly, with its innumerable delegates, many of whom were scientists, should be viewed with deep respect by the rest of the world. According to Janssen, the scope of the Washington Conference was "entirely moral in character and should be the counterpoint of no less valid interests of consideration, leaving the independence of each individual state absolutely intact" (Protocols..., 1884, p.24). According to him, one of the advantages of the conference was that it was comprised not only of experts, but also staffed by state officials, who were not familiar with scientific issues and were responsible for examining this issue from a 
political standpoint. He then proposed the motion of the adoption of "a prime meridian with a totally neutral character; exclusively chosen in such a way as to ensure general benefits to science and international commerce, which especially did not cut across any great continent: neither Europe nor America. (Protocols..., 1884, p.24). This defense of the scientific neutrality of choice underscores the rhetorical character of the French delegates, since they had no other argument against the widespread use of the Greenwich meridian by various countries of the world.

It is possible to divide the discussions up into two blocks: the French block, which was based on the argument of a totally neutral meridian, without a national footprint; and the Anglo-Saxon block, which championed the aspect of practicality. Favorable positions in Greenwich, advocated mainly by Britain and the United States, ${ }^{4}$ reiterated the utilitarian arguments, like the one already stated in Rome, whereby most of the world fleet already navigated using the English meridian. During the event, France defended the meridian of the island of Ferro, for historical reasons, which harked back to the geography of Ptolemy, but they themselves acknowledged that it was a French meridian disguised by the fact that geographer Guilherme Delisle, a contemporary of Cardinal Richelieu, had rounded up the meridian of the island of Ferro to $20^{\circ}$ west of the Paris Observatory, because on Ferro island there was no observatory. The French delegation was aware that this fact would prejudice the choice of that meridian as being absolutely neutral and further advocated a neutral meridian that did not pass through densely populated and as yet unspecified regions. As if the decision in favor of the weight of tradition and history was not enough, the French affirmed that it was the mission of that conference to choose a prime meridian that heeded the criterion of supranational neutrality (Protocols..., 1884).

In a letter to Emperor Pedro II, Luiz Cruls, the representative of Brazil at that conference and director of the Imperial Observatory of Rio de Janeiro, wrote about the dynamics of the conference suggesting that, in his opinion, it would not reach a satisfactory conclusion if large maritime nations did not come to a unanimous agreement. "France will never accept to abandon its meridian to adopt that of any other great nation, and certainly any other power would adopt the same stance" (Cruls, 16 out. 1884).

At that conference, Luiz Cruls was also a member of the committee together with Janssen and General Strachey of England, which was a prominent position. They had the duty to make the daily corrections of the minutes of the day and translate them into French and English, for the bilingual publication of the annals.

But what was at stake in this dispute over the prime meridian? Was it the offense to national self-esteem, to use an expression of the time, or was it a misrepresentation of the scientific concept? The Washington Conference can be analyzed as a privileged moment to understand the transformation of the notion of science as a universal and disembodied asset of immediate national interests to something justified by the reason for its effectiveness in economic and geopolitical circumstances. The role of technology was also central to these debates and its relationship with science was also to become increasingly intimate in the generations to come, both from the perspective of its practice and from the public apprehension of science. In other words, ideologically, science developed out of a perception of 
itself as something inherent in the plan merely linked to the theory and construction of a worldview, coming to be seen and validated by its practical applications together with technology.

It is also important to recall the speech of Spanish Minister Juan Valera. He had decided in favor of Greenwich but expected that England would adopt the French decimal metric system (Protocols..., 1884, p.38). The universality of the decimal system was a frequent point in the debates, championed by the French, and presented as a model to be followed to devise a system without national overtones. The fact that the English did not accept the metric system as an obstacle to the universalization of science permeated the speech of several delegates. In this sense, the Spanish vote expressed a widespread concern both in the Rome and Washington Congresses, that the adherence of England to the Metro Convention (1875) was an important step towards the universalization and standardization of scientific terminology. It is worth mentioning that it was within the scope of the Paris Academy of Sciences in the mid-eighteenth century that the decimal metric system was developed and is an astronomical measure, since it consists in determining the meter in $1 / 100$ th of the arc of 1 second of the terrestrial meridian

On October 22, 1884, the International Conference closed with a series of considerations on the prime meridian and the universal hour. Resolution II stated that: "The conference proposes to the governments represented here to adopt the meridian passing through the center of the meridian instrument of the Greenwich Observatory as the prime meridian for longitudes" (Protocols..., 1884, p.199). This decision was approved by 22 votes in favor, with abstentions of France and Brazil and only one vote against, of Santo Domingo.

\section{Brazil and the Washington Conference}

The most recent historiography of science in Brazil has its own battles, for example, to show that there was a national scientific production before the advent of universities and that the "center/periphery" binomial hardly serves as an explanatory key to the Brazilian history of science. It is important to be aware of the traps that can lead to statements that have become obstacles to the understanding of a tradition of scientific activity in Brazil.

An example of this type of production that neglects the history of science in Brazil can be seen in Junqueira (2012), which is about a voyage around the world of US Navy captain Charles Wilkes. Some points of that text in which the author presents a version of Brazilian participation at the Congress of Washington of 1884, the objective of which was to establish a universal prime meridian for the calculation of the hour, is discussed here; the result was the recommendation of the adoption of the Greenwich meridian as zero longitude.

Mary Junqueira (2015, p.17) deals with the same theme as the article analyzed here, in which the author states that this was not a book about the history of science. Thus, we see that Junqueira deliberately closed the doors on the production of the area of the history of the science, which prejudiced it in the development of its analysis on a trip that was considered to be "scientific." 
As far as the question of longitude is concerned, the author confuses the problem of the precision of the calculation of longitude in the high seas, resolved with Harrison's clock in the eighteenth century, with its need for standardization and universalization, a challenge of the nineteenth century due to novelties such as the telegraph and steam navigation. And when she cites the participation of the Brazilian representative, it becomes clear that she did not read the respective annals, as will be demonstrated here.

The interpretation in the historiography about how Brazil voted in that congress was one of the motivations for writing this text. After reading the annals of the congress, the relationship between geopolitics and science was clear enough and visible in the clashes between France and the Anglo-Saxon block. However, by following the circumstances of the visit of the Brazilian representative, as well as the subsequent official report, it was possible to shed new light on the problem.

The fascination with the history of longitude has already seduced many science historians. A good example is Dava Sobel's highly popular book Longitude (2008), which resulted in the 1999 film production of the same name, directed by Charles Sturridge. In addition to popularizing the theme, Sobel's work has the merit of showing how the problem of longitude was solved in the eighteenth century in the navigation context. At that moment, the enigma was to know the exact longitude at sea, and the solution came, as mentioned above, with Harrison's clock (Sobel, 2008). In the next century, the problem was no longer the same. The profusion of national observatories contributed to a multiplicity of prime longitudes in maps that were circulating globally. At that time, with the telegraph, railways and steam navigation, the scenario changed, and the unification of longitude required an urgent solution, namely a sole longitudinal meridian for all nations, as demonstrated by Peter Galison (2003). ${ }^{5}$

If in the eighteenth century the challenge was precision, in the nineteenth century the catchword was standardization and unification of scientific language. Moreover, the difference was also in the fact that, in the first case, the issue was settled exclusively within the Royal Society of London, and in the following period one notes the addition in this equation of the national factor with specific colorations of the nineteenth century, or the solution should come from an agreement between nations, and no longer from a single agency.

This conference is often referred to as a point of convergence for the unification of the coordinates, taking into account the disputes between powerful nations, mixed with the impact of new technologies of the time. Given that the French and AngloAmerican bibliographies focus their analyses in their respective countries, leaving gaps on the participation of the other countries, which is perfectly understandable, we have the task of rewriting this event from another perspective, and in this way to construct the meaning of a narrative with the available sources to reflect on the problem of the institutionalization of astronomy, more specifically the strengthening of the Imperial Observatory in Rio de Janeiro and its implications for the construction of a scientific culture in nineteenth century Brazil. 


\section{Brazilian historiography and the Washington Conference of 1884}

In Brazilian historiography, there exists an interpretation that Luiz Cruls was merely an adjunct to France at the Washington Conference, a view that is perhaps marked by the commonplace of considering the weight of French influence in the Brazilian intellectual environment, especially in relation to the nineteenth century. This idea is reinforced, for example, in the book that celebrated the 185 years of the National Observatory, which reported Brazil's stance against the adoption of the Greenwich meridian as a demonstration that Brazil was simply submitting to the "French position against an English meridian" (Rodrigues, 2012, p.98). Mary Junqueira (2012, p.39) explained Brazil's alignment with France by the fact that "long-haul Brazilian ships traditionally used the Paris meridian." The reader will see that this statement is only partially true, as will be shown below. There are other interpretations, such as that of Jörn Seemann (2013), for whom the Brazilian stance was a simple search for recognition of national astronomy abroad, without specifying the role of the Brazilian contribution in that international forum. Although correct, to a certain extent, the general opinion is that these interpretations have little explanatory scope for the Brazilian presence in Washington. These ways of seeing Brazil in that assembly reinforce, albeit unintentionally, an image of Brazilian science in the nineteenth century, seen as peripheral and orbiting around European centers or an empty figure of contributions in an international event. In a capitalist world that structures itself based on the international division of labor, Brazil's position was far from being on an equal footing among other hegemonic countries, but that does not mean being in a position of absolute subordination. The challenge is to analyze this issue bearing in mind the context of international inequalities and to perceive Brazil as an agent of its own interests and not as a pawn in the game between the central countries.

Undoubtedly, from the standpoint used in this article, it is not justifiable to attribute Cruls' performance as mere submission to French pressure, but he wishes to show how the circumstances of his visit to the Congress refer to the specific and material issues to better exercise his office in Brazil. To break with the cliché about science in nineteenthcentury Brazil, it is important to pay more attention to the specificity of Luiz Cruls' vote, which affirmed the need to choose a "neutral" meridian to avoid rivalry between nations. From the point of view of Brazil's interest, the choice of a universal meridian is advisable, whatever the chosen one. "Our local charts are based on the nearest meridian given by the Observatory of Rio de Janeiro, which provides a starting point for geodesic and hydrographic operations in Brazil, connected with the same meridian" (Protocols..., 1884, p.81). He also cited the work of the American commission, led by Commander Green of the US Navy, to determine longitudes by telegraphy.

In this argument of Cruls it is seen that Brazil made use of three meridians: the main one being the Rio de Janeiro meridian, for the elaboration of national maps; the Paris meridian for coastal navigation; as well as the works of the American Coast and Geodetic Survey in the determination of longitude by telegraphy, diverging from the earlier affirmation of Mary Junqueira, that quoted only the Paris meridian. In this way, Brazil was prepared for any outcome of the congress. In 1885, in a geography journal, Cruls made his reasons more 
explicit, distinguishing between national meridians and of universal origin, emphasizing his position in relation to an ideal of neutrality, which the choice of meridian should follow. In the same article, Cruls (15 out. 1885, p.58) confessed that he was dumbfounded that in an assembly which "had so many wise men and eminent theoretical men, it was the utilitarian side of the question [in the case of Greenwich] that dictated the resolutions taken."

It is important to remember that he abstained from the vote on the adoption of the Greenwich meridian, because this choice had a more utilitarian character, which did not convince him, as it was a criterion that contradicted the paradigms of the neutrality of science. In his opinion, that line could not divide densely populated continents. Another reason pointed out by Cruls for the impracticality of the Greenwich meridian was French opposition, since, in the absence of general agreement, it would not be feasible to call it a "universal" meridian.

By all accounts, Cruls was instructed by the emperor to back the French vote at that congress. This information is in the same article of October 15, 1885 (p.62). However, the instruction was due to the fact that Pedro II was a foreign associate of the Institute of France, which had asked him for his support in that international congress (a fact not published in the previous works cited on the theme of the Congress of 1884). This speaks more to the fact that Brazil is a monarchy, in which the limits of the public and private are diluted making them unclear (Schwarcz, 1998). Thus, state politics was confused with the person of the emperor, and the vote aligned with France was more an expression of this policy than a direct indication of the status of science in the country.

The solution of the problem for Cruls was to hark back to the ancients, like Marino de Tyro and Ptolemy, with some modification, namely to place the meridian next to the Azores. Or cast it on an island in the ocean that separates Asia from America "where the new world shakes hands with the old" (Cruls, 15 out. 1885, p.61). On this island an international observatory with a network of telegraphs should be built to meet the technical-scientific needs of the time. For him, both meridians would circumvent the dangers of a national meridian, and the point of reference could be perfectly calculated by modern astronomy.

In the corridors of the Congress there was collusion between Brazil and France, and the echoes of Cruls' vote also reverberated in the Bureau des Longitudes yearbook, when the French delegate Pierre J.C. Janssen, then director of the Meudon Observatory, partially reproduced Cruls' positions as an argument of authority, emphasizing that the mission of that assembly was to find a meridian of absolute neutrality and it could therefore not be a national meridian - and that the best practical decision should be made in the field of pure science (Janssen, 1886, p.864). It is important to see Cruls' effort to show that Brazil was a sovereign country where scientific institutions developed their own ideas about this topic. He also stated that he would vote against France if France were to propose Paris as the initial meridian. This fact was not mentioned by Janssen in his work.

Given that Santo Domingo, Brazil and France opposed the adoption of the Greenwich meridian, it is worth mentioning that the vote of Santo Domingo, was made by its Minister Galvan, who favored France for his admiration for a "nation recognized for being the leader in intellectual progress" (Protocols..., 1884, p.196), without adding much to the debate. 
When comparing this vote with the Brazilian vote, it is clear that Brazil's participation was considerably more eloquent.

For Howse (1985), the main impact of the Washington Conference was the progressive adoption of Greenwich as the prime meridian, which was a process that was completed in the first decades of the twentieth century and was universally adopted. According to Sabina Luz, it was in Article 2 of Law 2,784, dated June 18, 1913, that the Brazilian Legal Hour was established. This law allowed the adoption of the Greenwich meridian as a longitudinal reference for the country. In doing so, Brazil officially adopted the international hour system that gained an increasing number of adherents at this time (Luz, 2014, p.15).

Thus, at the threshold of the First World War, Brazil was inserted, in terms of longitude and universal time, into the global order. However, the circumstances of Cruls' voyage in 1884 have a number of elements that merit further explanation, as will be seen below.

The preparations for the event began with the USA issuing invitations to friendly nations in December 1883. In March of the following year, a letter from Cruls persuaded the emperor to send him as representative of the country, using arguments of territorial expanse.

Regarding the invitation addressed to the Government of Brazil, I think it would be convenient for this country to be represented in the upcoming congress, since this is a matter the solution of which is of great importance to the Brazilian empire, as the leading 'South American power' and being one of the four countries of 'greatest surface area of the whole world' (Cruls, 3 mar. 1884; our highlights).

In the abovementioned letter, the rhetorical use of Brazilian territorial expanse was explicit as a strong persuasive element, added to the pretensions of the "South American power" of the Brazilian Empire, not only to persuade Pedro II but also to instruct him how to act in order to confirm the position of Brazil in that event. This relation between territorial expanse and its position as a player in the southern hemisphere can be considered a long-lasting feature of the Brazilian geopolitical discourse.

By the time the invitation to the conference arrived, Cruls was feverishly working, in the words of Henry Morize, on the printing of the yearbook of 1885 and in the calculations of the observations of the passage of Venus in the expedition in 1882, the publication of which was already being demanded by the Rio de Janeiro press. Considering the good progress of the work, he evaluated that he could move away from the observatory and accept this invitation, which would be an opportunity to implement the necessary improvements in his institution (Morize, 1987, p.98). Luiz Cruls was acting director of the Imperial Observatory from 1881 and was elected by decree in August 1884. In other words, his participation in the Washington Congress was his first activity as official director.

Most probably thinking of promoting his institution, Cruls instructed his wife to send a note about him and the observatory, in an important journal, to his friend Gusmão Lobo of Jornal do Commercio: "'Some words in the newspaper are never amiss', especially during my absence" (Cruls, 31 out.; our emphasis added). It should be noted that this request was also emphasized in a post-written note in the same letter. This perception that it was necessary to be present even when absent is an important indication of the aforementioned 
process of institutionalization and the search for legitimation of scientific activity. Cruls' position as director was also at stake, since at that time he was in direct conflict with the Escola Politécnica and Pereira Reis on the calculation of the Rio de Janeiro meridian, as they had established another observatory on the Morro de Santo Antônio (Barboza, 1995; Oliveira, Videira, 2003). This dispute was on the pages of major newspapers and magazines, such as Agostini's Revista Ilustrada, circulating in Rio de Janeiro. In his management, Cruls' clear intention was to consolidate the observatory as the institution responsible for a fundamental feature for the nation state, namely the determination of territorial limits. One of the main missions of the observatory was the establishment of the geographical coordinates through the services of geodesy and position astronomy. It is also important to note that this matter took up much of his career as an astronomer in Brazil. As soon as he arrived here in 1874, Cruls had been appointed a member of the Commission of the General Charter of the Empire, in which he was in charge of purchasing the astronomy instruments of position and topography and he was professor of the subject at the Military School, as well as having pioneered demarcation works both nationally and internationally. In the Republic, he was the head of the Central Plateau Exploration Commission in 1892 and the Brazil-Bolivia Joint Demarcation Commission in 1901. The question of longitude was always a concern in his career.

In his travel report, Cruls (quoted in Barreto, 1987, p.109) stated that for the execution of such a service, a place with better atmospheric conditions than those on morro do Castelo was necessary. The demand for better working conditions and the hiring of more astronomers was a constant request in his official correspondence and in reports throughout his career, as well as in the letters to Maria Cruls. In analyzing this correspondence, the role she played in that institution beside her husband was clear for all to see. It was to her that Cruls asked to intercede with the director of an office of the Empire, Nicolau Midosi, ${ }^{6}$ to obtain more information on the situation of the long-awaited construction. Far from the institution, she was his spokesman, for in a letter dated August 28 he recommended: "Send my praise to the friends of the Observatory." In the first letter of Maria Cruls one can confirm this partnership as transcending the private sphere. She reported the internal disputes between astronomers Juliao de Oliveira Lacaille and Luiz da Rocha Miranda, manifesting clearly in favor of the latter and calling the former a snake, censoring him for the poor example he gave to other officials of the institution, for his scant attention to his work.

The content of these letters reveals an aspect as yet little explored in the historiography of science in Brazil, which is the role of women in the life of scientific institutions. At that time, they were not part of the staff of astronomers or technicians involved in their sphere of activities. In a strongly patriarchal and hierarchical society based on gender category, it was relatively common for wives to participate in the scientific careers of their husbands, since their insertion into the world of science on their own merits was not possible.

In the letter to her husband, she clarified what was observed during these discussions, namely the lack of news in the Brazilian press about the congress. This clearly demonstrates that what was being discussed there was of very little importance in everyday life in Brazil. Unlike the US, where the public followed the discussions closely, as there was the fear that with the adoption of a different meridian from the Greenwich meridian the decimal 
metric system for weights and measures would follow, which would have a great impact on American daily life where the biometric system of feet, inches and miles was used.

In the same trip, Cruls included Europe on his route, which became the central objective, as can be seen in the title of his report: "On the result of the visit to some of the major Observatories of Europe and the United States" (Cruls, 1885). It is interesting to note that in this document there is no mention of the Washington Congress. Only in the first part of the Ministerial Report of the Empire, which recorded the main occurrences in the institutes of the Empire, there was a brief mention that the director of the Imperial Observatory went to represent Brazil at the International Congress of the Prime Meridian and was replaced by the Baron of Parima, returning to his functions in January 1885 (Cruls, 1885, p.53). One of the main reasons for going to Europe was to monitor the construction of a meridian circle to be created by the manufacturer of scientific instruments Repsold, in Hamburg.

During his visit to the United States, Cruls visited a series of astronomical and meteorological observatories, and a constant aspect in his report is his observation regarding the scientific instruments and the location of the observatories in relation to the cities. At the Central Park Meteorological Observatory in New York, he observed: "The location of the instruments is not very suitable, being placed on the roof of the building, as despite the precautions taken, the thermometric instruments must suffer due to the reverberation on the surface of the zinc" (Cruls, 1885, p.1).

In his report, his enthusiasm regarding the Electricity Exhibition in Philadelphia was evident. In Washington, he went to the Naval Observatory, which is the American National Observatory. There, in addition to the description of the instruments, Cruls went into detail on the question of the service of the distribution of the hour, which, at that moment, occurred by telegraph at noon for the entire territory. On this subject, he also mentioned the relationship of the American rail system and time zones, "because of the enormous extent of the territory in terms of longitudes" (Cruls, 1885, p.6). Unlike Brazil, which has three time zones in sparsely populated regions and without a substantial railway network, there was little interest of the public in the event of 1884 .

While in that institution, Cruls focused on a matter that was very important to him: the transfer of the observatory, due to the proximity to the city. During this visit, he acquired the construction plans of the new American observatory, and most probably it was no coincidence that he converted the cost of this construction in dollars into Brazilian currency: 1,000:000\$000 (Cruls, 1885, p.6). If there was one thing Cruls was really concerned about at that time, it was the relocation of the Rio de Janeiro Observatory, and he and his wife even devised a strategy of buying an instrument that could not be housed in the Castelo Observatory, thereby requiring the transfer of same to another area.

\section{Final considerations}

From his voyage, Cruls brought copies of building plans of the Meudon Observatory in his luggage for the construction of his long-cherished new observatory. He did not, however, live to see the new building on the morro de São Januário, inaugurated in 1921, during the administration of Henrique Morize. 
To bring to the fore the objective interests of buying instruments and constructing new buildings for his scientific institution, it makes it feasible to surmise that the Brazilian representative's vote followed the French vote. Thus, it can be assumed that Cruls was actively pursuing his own interests, like the other congressmen, being as qualified as the others to seek conditions to fully exercise his office. For this, he played with the cards he possessed, appealing rhetorically to the ruler's instinct for a national solution. In this way, the nation can be seen not as something essentially important or good, but as a high value discursive device in the negotiation process.

The issue of longitude in Brazil is an unexplored topic in historiography and can elicit a more systematic reflection on the relationship between astronomy and Brazilian territorial formation, as well as the institutionalization of astronomy in the country. It was around the calculation of longitude, for example, that a controversy occurred between the astronomers of the Imperial Observatory and those of the Polytechnic School. Discussions about longitude are indeed a valid route to be followed for the verification of the relations between science and knowledge regarding the Brazilian territory and its repercussions in the formation of a scientific culture in Brazil.

One of the objectives of this article was to discuss with a bibliography that explains the Brazilian vote at the Washington Conference as mere "obedience" to France, reinforcing the interpretive key of Brazil of the nineteenth century as being without intellectual autonomy and with its eyes always focused on the European capitals. Thus, in looking closely at the circumstances of Luiz Cruls' voyage in 1884, the intention was to show readers that such arguments are not only misleading, but also do not assist in understanding the cultural life of the Second Empire in Brazil. One of the reasons for the criticism of this bibliography is to point out that science is part of the cultural and intellectual life of countries such as Brazil, and that an understanding of this interrelationship is vital for the production of a consistent and relevant historiography. This may be rendered feasible when the boundaries between sub-areas of history are more frequently transposed.

\section{NOTES}

* A first version of this article was published as the chapter of a book entitled "Astronomy in Brazil and the circumstances of the Washington Congress in 1884" (Vergara, 2015). It should be noted that the chapter has a commemorative character, whereas this article is a critical and concise analysis and seeks to establish a historiographic debate within the scope of Revista História, Ciências, Saúde - Manguinhos.

${ }^{1}$ For further information on the context of this conference, see Galison (2003).

${ }^{2}$ Levasseur was the editor of the book Le Brésil, on the occasion of the Universal Exhibition in Paris in 1889, in collaboration with the Baron of Rio Branco and Eduardo Prado.

${ }^{3}$ That was the moment when Pereira Reis was attacking the observatory and its director Emmanuel Liais in the press of the capital of the Empire, alleging the incompetence of the institution for the determination of the longitude of Rio de Janeiro.

${ }^{4}$ The North American adhesion to Greenwich is due to the fact that there was an internal dispute between the states for the national meridian.

${ }^{5}$ On this topic, see also Bartky (2007), Howse (1980) and Gapaillard (2011).

${ }^{6}$ Nicolau Midosi is better known in historiography for having been the editor of Revista Brasileira between 1879 and 1881 (Vergara, 2015). 


\section{REFERENCES}

BARBOZA, Christina Helena.

Entre o céu e a terra: astrônomos e engenheiros na polêmica do meridiano absoluto. Perspicillum, v.9, n.1, p.5-23. 1995.

BARRETO, Luiz Muniz.

Observatório Nacional: 160 anos de história. Rio de Janeiro: MCT, CNPq. 1987.

BARTKY, Ian R.

One time fits all: the campaigns for Global Uniformity. California: Stanford University Press. 2007.

CRULS, Luiz.

Sobre o resultado da visita a alguns dos principais Observatórios da Europa e dos Estados Unidos. In: Brasil. Ministério do Império. Ministro João Florentino Meira de Vasconcello. Relatório do Ano de 1884, apresentado à Assembleia Geral Legislativa na $1^{\text {a }}$ sessão da $19^{\text {a }}$ Legislatura, anexo D. 1885.

CRULS, Luiz.

Conferência Internacional para adoção de um meridiano inicial único. Revista da Seção da Sociedade e Geografia de Lisboa no Brasil, $2^{\mathrm{a}}$ série, n.2, p.54-65. 15 out. 1885 .

CRULS, Luiz.

Cartas de Cruls para Mariquinha. Arquivo Mast, Rio de Janeiro. 31 out. 1884.

CRULS, Luiz.

Carta de Cruls para o Imperador. Acervo Museu Imperial, Petrópolis. 16 out. 1884.

CRULS, Luiz.

Cartas de Luiz Cruls ao Imperador Pedro II. Acervo do Museu Imperial, Petrópolis. 3 mar. 1884.

GALISON, Peter.

Os relógios de Einstein e mapas de Poincaré: impérios do Tempo. Lisboa: Gradiva. 2003.

GAPAILLARD, Jacques.

Histoire de l'heure en France. Paris: Vuibert-Adapt. 2011.

HIRSCH, Adolph; OPPOLZER, Theodor von. Unification des longitudes par l'adoption d'un méridien initial unique, introduction d'une heure universelle: extrait des Comptes Rendus de la Septième Conférence Générale de L'Association Géodésique Internationale, réuni à Rome, en Octubre 1883. Rome: Bureau Central de L'Association Géodésique Internationale. 1883.

HOWSE, Derek.

1884 and Longitude Zero. Vistas in Astronomy: an international review journal, v.28, parts $1 / 2$, p.11-22. 1985.
HOWSE, Derek.

Greenwich time and the discovery of longitude. Oxford: Oxford University Press. 1980.

JANSSEN, Pierre Jules César

Notice sur le méridien et l'heure universels. Annuaire du Bureau des Longitudes, p.835-881. 1886.

JUNQUEIRA, Mary Anne.

Velas ao mar: U.S. Exploring Expedition (18381842) - a viagem científica de circum-navegação dos norte-americanos. São Paulo: Intermeios; Fapesp. 2015.

JUNQUEIRA, Mary Anne.

Os objetivos da circunavegação da U.S. Exploring Expedition (1838-1842): longitude, mapeamento náutico e instituição das coordenadas geográficas modernas. História, Ciências, Saúde - Manguinhos, v.19, n.1, p. 2748. Disponível em: <http://dx.doi.org/10.1590/ S0104-59702012000100003>. Acesso em: 6 nov. 2012. 2012.

LUZ, Sabina Ferreira Alexandre. O estabelecimento da Hora Legal Brasileira: o Brasil adota o meridiano de Greenwich. Dissertação (Mestrado em História) - Universidade Federal Fluminense, Niterói. 2014.

MORIZE, Henrique.

Observatório astronômico: um século de história (1827-1927). Rio de Janeiro: Mast, Salamandra. 1987.

OLIVEIRA, Januária. T. de; VIDEIRA, Antonio Augusto dos P.

As polêmicas entre Manoel Pereira Reis, Emmanuel Liais e Luiz Cruls na passagem do século XIX. Revista da SBHC, v.1, n.1, p.42-52. 2003.

PROTOCOLS...

Protocols of the proceedings. International Conference held at Washington for the purpose of fixing a Prime Meridian and a Universal Day. October, 1884. Washington, DC: Gibson Bros., Printers and Bookbinders. 1884.

RODRIGUES, Teresinha de Jesus Alvarenga. Observatório Nacional 185 anos: protagonista do desenvolvimento científico-tecnológico do Brasil. Rio de Janeiro: Observatório Nacional. 2012.

SCHWARCZ, Lilia M.

As barbas do imperador: D. Pedro II, um monarca nos trópicos. São Paulo: Companhia das Letras. 1998.

SEEMANN, JÖRN.

Linhas imaginárias na cartografia: a invenção do primeiro meridiano. Geograficidade, v.3, número 
especial, p.31-44. Disponível em: <https://doi. org/10.22409/geograficidade2013.30.a12872>. Acesso em: set. 2014. 2013.

SOBEL Dava.

Longitude: a verdadeira história do gênio solitário que resolveu o maior problema do século XVIII. São Paulo: Companhia das Letras. 2008.
VERGARA, Moema.

A astronomia no Brasil e as circunstâncias do Congresso de Washington em 1884. In: Barboza, Chrisitina H. (Org.). Mast, 30 anos de pesquisa. v.3. Rio de Janeiro: Mast. Diponível em: <http:// site.mast.br/hotsite_mast_30_anos/pdf_03/ volume_03.pdf>. Acesso em: 24 ago. 2017. 2015. 